\title{
New Paleogene mantises from the Oise amber and their evolutionary importance
}

Thomas Schubnel and Andre Nel

Acta Palaeontologica Polonica 64 (4), 2019: 779-786 doi:https://doi.org/10.4202/app.00628.2019

Mantodea are rather scarce in the fossil record, especially those belonging to the mantise crown group. Four fossil mantids are described from the lowermost Eocene amber of Oise (France), two Chaeteessidae considered as "genus and species incertae sedis", and two Mantoididae, described as a new genus and species Pseudomantoida extendidera. We also describe a new specimen of Arvernineura insignis from the Paleocene of Menat (France), confirming the attribution of this taxon to the Chaeteessidae. These fossils are of great interest for future dating of the crown group Mantodea, being the oldest Chaeteessidae and Mantoididae. We propose a new genus name Louispitonia nom. nov. in replacement of Archaeophlebia Piton, 1940 preoccupied by Archaeophlebia Ris, 1909 (Odonata) with Archaeophlebia enigmatica as its type species.

Key words: Insecta, Mantodea, Chaeteessidae, Mantoididae, Paleocene, Eocene, France.

Thomas Schubnel [thomas.schubnel@wanadoo.fr] and Andre Nel [anel@mnhn.fr] (corresponding author), Institut Systématique Evolution Biodiversité (ISYEB), Muséum national d'Histoire naturelle, CNRS, Sorbonne Université, Université des Antilles, EPHE, 57 rue Cuvier, CP 50, 75005 Paris, France.

This is an open-access article distributed under the terms of the Creative Commons Attribution License (for details please see creativecommons.org), which permits unrestricted use, distribution, and reproduction in any medium, provided the original author and source are credited. 
